Research article

\title{
Cia5d regulates a new fibroblast-like synoviocyte invasion-associated gene expression signature
}

\author{
Teresina Laragione ${ }^{1}$, Max Brenner ${ }^{1}$, Wentian $\mathrm{Li}^{2}$ and Pércio S Gulko ${ }^{1,3}$
}

\author{
'Laboratory of Experimental Rheumatology, Center for Genomics and Human Genetics, Feinstein Institute for Medical Research, 350 Community \\ Drive, Manhasset, New York 11030, USA \\ ${ }^{2}$ Genomics and Human Genetics, Feinstein Institute for Medical Research, 350 Community Drive Manhasset, New York 11030, USA \\ ${ }^{3}$ Department of Medicine, New York University School of Medicine, 550 First Avenue, New York, 10016, USA \\ Corresponding author: Pércio S Gulko, pgulko@nshs.edu
}

Received: 18 Apr 2008 Revisions requested: 21 May 2008 Revisions received: 17 Jul 2008 Accepted: 15 Aug 2008 Published: 15 Aug 2008

Arthritis Research \& Therapy 2008, 10:R92 (doi:10.1186/ar2476)

This article is online at: http://arthritis-research.com/content/10/4/R92

(C) 2008 Laragione et al.; licensee BioMed Central Ltd.

This is an open access article distributed under the terms of the Creative Commons Attribution License (http://creativecommons.org/licenses/by/2.0), which permits unrestricted use, distribution, and reproduction in any medium, provided the original work is properly cited.

\begin{abstract}
Introduction The in vitro invasive properties of rheumatoid arthritis (RA) fibroblast-like synoviocytes (FLSs) have been shown to correlate with disease severity and radiographic damage. We recently determined that FLSs obtained from pristane-induced arthritis (PIA)-susceptible DA rats are also highly invasive in the same in vitro assay through Matrigel. The transfer of alleles derived from the arthritis-resistant F344 strain at the arthritis severity locus Cia5d (RNO10), as in DA.F344(Cia5d) congenics, was enough to significantly and specifically reduce the invasive properties of FLSs. This genetically controlled difference in FLS invasion involves increased production of soluble membrane-type 1 matrix metalloproteinase (MMP) by DA, and is dependent on increased activation of MMP-2. In the present study we aimed to characterize the pattern of gene expression that correlates with differences in invasion in order to identify pathways regulated by the Cia5d locus.

Methods Synovial tissues were collected from DA and DA.F344(Cia5d) rats 21 days after the induction of PIA. Tissues were digested and FLSs isolated. After a minimum of four passages, FLSs were plated on Matrigel-covered dishes at similar densities, followed by RNA extraction. Illumina RatRef-12 expression BeadChip arrays were used. Expression data were normalized, followed by $t$-test, logistic regression, and cluster

analysis. Real-time PCR was used to validate the microarray data.

Results Out of the 22,523 RefSeq gene probes present in the array, 7,665 genes were expressed by the FLSs. The expression of 66 genes was significantly different between the DA and DA.F344(Cia5d) FLSs $(P<0.01)$. Nineteen of the 66 differentially expressed genes $(28.7 \%)$ are involved in the regulation of cell cycle progression or cancer-associated phenotypes, such as invasion and contact inhibition. These included $\mathrm{Cxc} / 10$, Vil2 and Nras, three genes that are upregulated in DA and known to regulate MMP-2 expression and activation. Nine of the 66 genes (13.6\%) are involved in the regulation of estrogen receptor signaling or transcription. Five candidate genes located within the Cia5d interval were also differentially expressed.

Conclusions We have identified a novel FLS invasion associated gene expression signature that is regulated by Cia5d. Many of the genes found to be differentially expressed were previously implicated in cancer cell phenotypes, including invasion. This suggests a parallel in the behavior of arthritis FLSs and cancer cells, and identifies novel pathways and genes for therapeutic intervention and prognostication.
\end{abstract}

\section{Introduction}

Rheumatoid arthritis (RA) is a common chronic autoimmune disease that affects approximately $1 \%$ of the population [1]. It is a complex trait, in which genetic and environmental factors mediate disease susceptibility and severity [1]. Basic joint pathology in RA is characterized by pronounced synovial hyperplasia, also called 'pannus', which produces several proinflammatory cytokines and proteases and, like a malignant tumor, invades and destroys cartilage and bone [2-4].

CXCR: C-X-C chemokine receptor; DMEM: Dulbecco's modified Eagle's medium; ER: estrogen receptor; FLS: fibroblast-like synoviocyte; GAPDH: glyceraldehyde-3-phosphate dehydrogenase; MMP: matrix metalloproteinase; MT1: membrane-type 1; PCR: polymerase chain reaction; RA: rheumatoid arthritis. 
The formation of the synovial pannus is regulated by complex interactions between synovial resident cells and infiltrating inflammatory cells $[5,6]$, and their production of paracrine and autocrine factors such as cytokines and growth factors [7-9], nuclear factor-kB activation [10], and angiogenesis [11]. The fibroblast-like synoviocyte (FLS) is a key player in this process, and its numbers are markedly increased in the hyperplastic synovial pannus of RA and rodent models of arthritis [4]. RA FLSs invade cartilage [12] and produce increased amounts of several proteolytic enzymes that further contribute to joint destruction [2,3]. The invasive properties of RA FLSs have also been associated with radiographic damage in RA, a parameter of disease severity, which emphasizes their direct clinical relevance [13].

We have previously identified Cia5d as an arthritis severity locus and showed that DA.F344(Cia5d) rats congenic for this interval developed significantly milder arthritis, with nearly no pannus formation and neither bone nor cartilage destruction, as compared with highly susceptible DA rats [14]. We also determined that Cia5d regulates the invasive properties of FLSs, thus providing an explanation for its role in joint damage [15]. The arthritis gene located within Cia5d controls the FLS production of soluble membrane-type 1 (MT1)-matrix metalloproteinase (MMP) and activation of MMP-2 [15]. This was the first time that FLS phenotypes were found to be genetically regulated.

In the present study we took advantage of this genetically regulated FLS invasive phenotype and compared highly invasive with minimally invasive cells' gene expression signatures using microarrays. The study of more than 22,000 genes identified a gene expression signature related to invasion that is differentially regulated between FLSs from DA and DA.F344(Cia5d) rats. The novel FLS invasion pathways described here resemble those described in cancer cell lines and have the potential to become novel targets for therapeutic intervention.

\section{Materials and methods Rats}

DA (DA/BkIArbNsi, arthritis-susceptible) inbred rats (originally from Bentin \& Kingman, CA, USA) were maintained at the Arthritis and Rheumatism Branch (Arb; National Institutes of Health) and then transferred to the Feinstein Institute (previously named North Shore-LIJ Institute; Nsi). The genotypeguided breeding of DA.F344(Cia5d) was previously described in detail [14]. Briefly, a 37.2 megabase interval on rat chromosome 10 was transferred from F344 into the DA background over 10 backcrosses followed by at least five intercrosses (Figure 1). The experiments were conducted with rats homozygous at the congenic interval. All experiments involving animals were reviewed and approved by the Feinstein Institute for Medical Research Institutional Animal Care and Use Committee. Animals were housed in a pathogen free
Figure 1

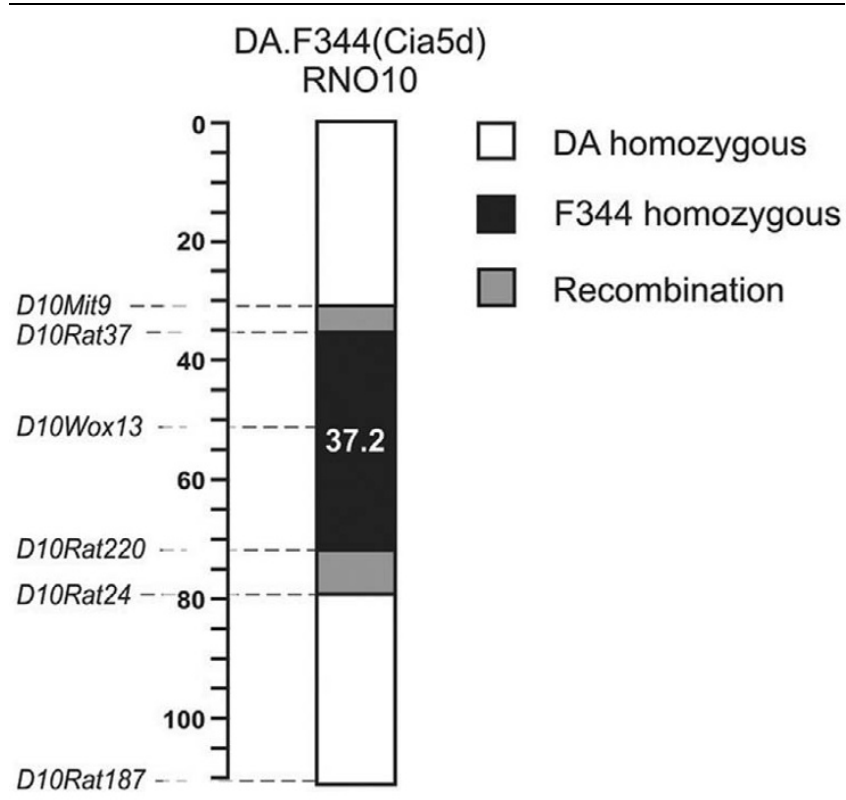

Map of Cia5d congenic interval. Markers used in the breeding of DA.F344(Cia5d) congenics and their positions on chromosome 10. Numbers represent the position in the chromosomes. Mb, megabases.

environment, on 12-hour light and dark cycles, with free access to food and water.

\section{Induction of PIA and arthritis scoring}

Rats aged 8 to 12 weeks received $150 \mu$ of pristane by intradermal injection divided into two sites at the base of the tail $[14,16]$. The animals were scored on days 14,18 and 21 after pristane induction using a previously described arthritis scoring system $[17,18]$. On day 21 after injection, the animals were killed and synovial tissue was collected from the ankles for FLS isolation.

\section{Isolation and culture of primary FLS}

FLSs were isolated by enzymatic digestion of the synovial tissue. Briefly, tissues were minced and incubated with a solution containing DNase $0.15 \mathrm{mg} / \mathrm{ml}$, hyaluronidase type I-S 0.15 $\mathrm{mg} / \mathrm{ml}$, and collagenase type IA $1 \mathrm{mg} / \mathrm{ml}$ (Sigma-Aldrich, St. Louis, MO, USA) in Dulbecco's modified Eagle's medium (DMEM; Gibco, Invitrogen Corporation, Carlsbad, CA, USA) for 1 hour at $37^{\circ} \mathrm{C}$. Cells were washed and re-suspended in DMEM supplemented with 10\% fetal bovine serum (Gibco), glutamine $30 \mathrm{mg} / \mathrm{ml}$, amphotericin B $250 \mu \mathrm{g} / \mathrm{ml}$ (Sigma), and gentamicin $10 \mathrm{mg} / \mathrm{ml}$ (Gibco). After overnight culture, nonadherent cells were removed and adherent cells were cultured. All experiments were performed with cells after passage four (95\% FLS purity).

\section{Flow-cytometric characterization of FLSs}

Freshly trypsinized FLSs (105) were re-suspended in phosphate-buffered saline with $0.02 \%$ azide (Sigma-Aldrich) and 
$1 \%$ bovine serum albumin ( $\mathrm{P}$ Biomedicals, Aurora, $\mathrm{OH}, \mathrm{USA}$ ), and incubated with $1 \mu \mathrm{g}$ anti-CD32 (Pharmingen, San Diego, $\mathrm{CA}$, USA) to block Fc $\gamma$ II receptors. Cells were stained with saturating concentrations of CD90 (OX-7; PerCP, Pharmingen) or isotype control. Stained cells were fixed with $1 \%$ paraformaldehyde in phosphate-buffered saline and analyzed by flow cytometry in a FACSCalibur (Becton Dickinson, Franklin Lakes, NJ, USA), using the BD Cell-Quest ${ }^{\mathrm{TM}}$ Pro version 4.0.1 software (Becton Dickinson).

\section{FLS culture on Matrigel}

We previously studied the invasive properties of FLSs through a collagen matrix (Matrigel). Cell interactions with the extracellular matrix are known to influence the expression of several genes, including activation of MMP-2 [19], which is a key mediator of the FLS invasive phenotype. Therefore, in order to study the gene expression signature of highly invasive and minimally invasive FLSs, cells were cultured under the same conditions as used in the invasion studies. Specifically, 100\% confluent $75 \mathrm{~cm}^{2} \mathrm{FLS}$ culture flasks were trypsinized (trypsin $0.25 \%$ with EDTA $0.1 \%)$. The rates of cellular proliferation differed among cell lines, and we previously showed that FLS proliferation does not correlate with the FLS invasive behavior. In order to have similar cell confluence at the time of FLS harvesting for RNA extraction, $10 \%$ to $50 \%$ of the high-density 75 $\mathrm{cm}^{2}$ cell culture flasks (depending on the cell line) were plated in Matrigel-coated $10 \mathrm{~cm}$ culture dishes (Becton Dickinson) with DMEM, 10\% fetal bovine serum, antibiotics, and glutamine. Cell cultures were maintained at $37^{\circ} \mathrm{C}$ with $5 \%$ carbon dioxide for 24 hours. After 24 hours, FLSs were harvested using a cell scraper (Corning, Acton, MA, USA) followed by digestion of the Matrigel with $10 \mathrm{ml}$ collagenase $D 1 \mathrm{mg} / \mathrm{ml}$ (Roche Applied Science, Indianapolis, IN, USA) at $37^{\circ} \mathrm{C}$ for 10 minutes. FLSs were then collected by centrifugation, washed twice with ice-cold phosphate-buffered saline. Cell pellets were re-suspended in RLT lysis buffer (RNeasy Mini Kit; Qiagen, Valencia, CA, USA) with $1 \%$ (vol/vol) $\beta$-mercaptoethanol (Sigma). Cell-lysis buffer suspension was vortexed, frozen in liquid nitrogen and stored at $-80^{\circ} \mathrm{C}$ until RNA extraction.

\section{RNA extraction and quality assessment}

Cells in RLT buffer were disrupted using QlAshredder spin columns (Qiagen), and total RNA was extracted using the RNeasy Mini Kit (Qiagen), in accordance with the manufacturer's instructions. Samples were digested with DNase (Qiagen) and eluted with $30 \mu \mathrm{l}$ RNase-free water. RNAs were quantified and assessed for purity using a NanoDrop spectrophotometer (Rockland, DE, USA). RNA integrity was verified with a BioAnalyzer 2100 (Agilent, Palo Alto, CA, USA).

\section{RNA preparation and microarray experiments}

The RatRef-12 Expression BeadChip contains 22,524 probes for a total of 22,228 rat genes selected primarily from the NCBI RefSeq database (Release 16; Illumina, San Diego, CA, USA), and was used in accordance with the manufacturer's instructions. All reagents have been optimized for use with Illumina's Whole-Genome Expression platform. Total RNA 200 ng was used for cRNA in vitro transcription and labeling with the TotalPrep ${ }^{\text {TM }}$ RNA Labeling Kit using Biotinylated-UTP (Ambion, Austin, TX, USA). Hybridization is carried out in Illumina Intellihyb chambers at $58^{\circ} \mathrm{C}$ for 18.5 hours, which is followed by washing and staining, in accordance with the Illumina Hybridization System Manual. The signal was developed by staining with Cy3-streptavidin. The BeadChip was scanned on a high resolution Illumina BeadArray reader, using a two-channel, $0.8 \mu \mathrm{m}$ resolution confocal laser scanner.

\section{Data extraction and normalization}

The Illumina BeadStudio software (Version 2.0) was used to extract and normalize the expression data (fluorescence intensities) for the mean intensity of all 12 arrays. Genes expressed in all 12 arrays were selected for analyses. Normalized data were analyzed using the $t$-test and logistic regression.

\section{Statistics and analyses}

The $t$-test was used to compare means of the log-transformed and non-log-transformed data. Genes with a $P$ value under 0.01 between DA and DA.F344(Cia5d) were considered significant and included in additional analysis. The logistic regression model fitting was carried out as previously described $[20,21]$ using the filtered gene list. The statistical significance of a logistic regression result was obtained by comparing the deviance with the 'null deviance'. This null deviance is the (2) log-likelihood of a random model in which the probability for a sample to belong to a group (for example, DA) is equal to the proportion of DA samples in the dataset. The difference between the deviance and the null deviance follows the $\chi^{2}$ distribution with one degree of freedom by chance alone, and this $\chi^{2}$ distribution was used to determine the $P$ value. The R statistical package [22] was used for $t$-test and logistic regression analyses.

The Ingenuity IPA 5.5.1 program (Ingenuity, Redwood City, CA, USA) and PubMed and GEO (Gene Expression Omnibus) searches were used for pathways detection. CLUSTER [23] and TREEVIEW [24] were used for cluster analysis and generation of a heat map.

\section{Quantitative real-time PCR}

The same RNA used for the microarray experiments was also used for the quantitative real-time PCR confirmation experiments. Total RNA $200 \mathrm{ng}$ from each sample was used for cDNA synthesis using the Superscript III kit (Invitrogen). Primers and probe sequences were designed to target the same exon as used in the lllumina RatRef-12 Expression BeadChip. We used Exiqon (Woburn, MA, USA) and Taqman (ABI, Applied Biosystems, Foster City, CA) probes (Table 1). GAPDH was used as endogenous control. Probes were labeled with FAM at the $5^{\prime}$ end and TAMRA at $3^{\prime}$ end and used at a final concentration of $100 \mathrm{nmol} / \mathrm{l}$. Primers were used at 
Table 1

Genes studied with QPCR for confirmatory studies, primers and probe sequences

\begin{tabular}{|c|c|c|c|c|c|}
\hline Accession number & Gene symbol & Target exonb & Probe & Forward primer & Reverse primer \\
\hline \multicolumn{6}{|l|}{ Up-regulated in DA } \\
\hline NM_139089.1 & Cxcl10 & 4 & Exiqon Universal probe 67 & TTCGGACCAGCTCTTAGAGAA & GCCTGGTCCTGAGACAAAAG \\
\hline XM_220552.3 & Trim16 & 6 & Exiqon Universal probe 1 & GTGAACTCCTTCCCАCTCCA & CAGCTGCATTTCTGGAAACA \\
\hline NM_017207.1 & Trpv2 & 15 & Exiqon Universal probe 6 & СТСТTСССАССТTАTСTGAGGA & GACCTGAAGGGGCAGATG \\
\hline NM_019357.1 & Vil2 & 13 & $\begin{array}{c}\text { CCCCAAGACCCAGTGGAA } \\
\text { TCCTCC }^{a}\end{array}$ & AGGTACCGGGCGATGTTCT & GGCCTGTTTGGCACTATGTGA \\
\hline LOC309362 & Dnmbp & 16 & Exiqon Universal probe 97 & TTGTCTCAGCATGGGTCCTA & ACCAGGATTTTAAGGCCACA \\
\hline NM_001107408 & Gins3 & $3-4$ & Exiqon Universal probe 17 & GTCGTGGACCTCCACAAAAT & GAACCGTCCAATAAAAGTCTGC \\
\hline \multicolumn{6}{|c|}{ Down-regulated in DA } \\
\hline XM_235434.4 & Gsdmdc1 & 13 & Exiqon Universal probe 68 & AGCACGTCTTGGAACAGAGC & TCСTCATCCCAGCTGTCC \\
\hline XM_222868.4 & Olfml2b & 8 & Exiqon Universal probe 106 & СТСССТTСТTССАТGСТСТG & GCAAGCCCCAGAGGAATAA \\
\hline NM_001008321.1 & Gadd45b & 4 & Exiqon Universal probe 25 & ACAGGTGGTCGCCAAGAC & CCAGGCCTTGGCTCTAAAGT \\
\hline \multicolumn{6}{|l|}{ Estrogen receptors } \\
\hline NM_012689.1 & Esr1 & - & Exiqon Universal probe 67 & GCAAGAATGTCGTGCCTCTC & TGAAGACGATGAGCATCCAG \\
\hline NM_012754 & Esr2 & - & Exiqon Universal probe 94 & CCTTGAAGGCTCTCGGTGTA & CAGAACCTTTCAGATGTTTCCA \\
\hline
\end{tabular}

aTaqman probe. ${ }^{b}$ Same region used in the Illumina microarray.

$200 \mathrm{nmol} / \mathrm{l}$ concentration with Eurogentec quantitative realtime PCR mastermix (Eurogentec, San Diego, CA, USA). The $\mathrm{ABI} 7700$ quantitative real-time PCR thermocycler was used at $48^{\circ} \mathrm{C}$ for 30 minutes, $95^{\circ} \mathrm{C}$ for 10 minutes, and 45 cycles of $95^{\circ} \mathrm{C}$ for 0.15 minutes and $60^{\circ} \mathrm{C}$ for 1 minute. Samples were run in duplicates and the means used for analysis. Data were analyzed using Sequence Detection System software version 1.9.1 (ABI). Results were obtained as $\mathrm{Ct}$ (threshold cycle) values. Relative expression of all the genes was adjusted for GAPDH in each sample $(\Delta \mathrm{Ct})$, and $\Delta \mathrm{Ct}$ used for $t$-test analysis. Quantitative real-time PCR fold differences were calculated with $2^{-\Delta \Delta \mathrm{Ct}}[25]$.

\section{Results \\ Characterization of the FLS cell lines used}

In previous studies we determined that DA FLSs were highly invasive, and that alleles derived from the arthritis-resistant strain F344 at the Cia5d interval, as in DA.F344(Cia5d) congenics (Figure 1), specifically reduced the invasive properties of FLSs. Additionally, FLSs from DA and DA.F344(Cia5d) strains expressed similar mRNA levels of transforming growth factor- $\beta$, tumor necrosis factor- $\alpha$, IL-1 $\beta$ and IL-6, as well as MMP-1, MMP-2, MMP-3, MMP-9, MMP-13, MT1-MMP and MT2-MMP [15]. Both strains had similar collagenase and MMP-3 activity, but levels of soluble MT1-MMP and active MMP-2 were increased in DA. MMP-2 inhibition reduced DA FLS invasion to levels similar to those of DA.F344(Cia5d). Cytoskeleton characteristics were also similar in DA and DA.F344(Cia5d) FLSs [15].
In the present study FLSs were stained with CD90, a marker for FLS [26], and analyzed by flow cytometry. Comparable numbers of $\mathrm{CD}^{+}{ }^{+}$cells were detected both in five different DA and five different DA.F344(Cia5d) rats (percentage of $\mathrm{CD}^{+}{ }^{+}$cells [mean \pm standard deviation]: DA $95.46 \pm 8.9$ and DA.F344 [Cia5d] $96.51 \pm 5.9$ ), demonstrating that the cell lines were homogeneously CD90+.

\section{Genes expressed by FLSs and filtering criteria}

A total of 7,665 genes out of 22,228 genes represented in the Illumina RatRef-12 BeadChip were expressed by both DA and DA.F344(Cia5d) FLSs. Log transformation did not significantly affect the list of differentially expressed genes, and therefore results are shown from analyses done with non-logtransformed data.

\section{Genes differentially expressed between DA and DA.F344(Cia5d) FLSs}

Sixty-six genes had a $P$ value under 0.01 (Tables 2 and 3 ) and were used for fold change calculations and pathway detection analyses. Thirty-six genes were expressed in increased levels by DA FLSs, and the presence of F344 alleles at the Cia5d interval, as in DA.F344(Cia5d) congenics FLSs, was enough to reduce their expression significantly (Table 2 ). Thirty genes were expressed in reduced levels in DA and significantly increased in DA.F344(Cia5d) FLSs (Table 3). These observations demonstrate that alleles within the Cia5d interval, the only genetic difference between DA and DA.F344(Cia5d), are directly or indirectly involved in the regulation of the expression of several genes, and the difference in gene expression correlates with the difference in invasive properties of FLSs. Fur- 
Table 2

Genes with reduced expression in synovial fibroblasts from DA.F344 (Cia5d) compared with highly invasive DA, including those associated with cancer-phenotypes and estrogen signaling

\begin{tabular}{|c|c|c|c|c|c|c|c|}
\hline Gene Symbold & Definitiona & Accession number & DA mean & Cia5d mean & Fold change & P value ${ }^{b}$ & Overall rank ${ }^{\mathrm{c}}$ \\
\hline \multicolumn{8}{|c|}{ Cancer, Cell Cycle, DNA replication, recombination and repair } \\
\hline Trim16_predictede & Tripartite motif protein 16 (predicted) & XM_220552.3 & 262.14 & 82.27 & -3.2 & 0.0033 & 23 \\
\hline Cxcl10 & Chemokine (C-X-C motif) ligand $10^{f}$ & NM_139089.1 & 1218.54 & 434.48 & -2.8 & 0.0001 & 2 \\
\hline$D n m b p$ & $\begin{array}{l}\text { Similar to Dynamin binding protein } \\
\text { (Scaffold protein Tuba) }\end{array}$ & XM_219860.3 & 739.97 & 385.61 & -1.9 & 0.0088 & 62 \\
\hline Vil2 & Villin 2 (Ezrin) $f$ & NM_019357.1 & 1642.95 & 984.09 & -1.7 & 0.0023 & 15 \\
\hline Nras & $\begin{array}{l}\text { Neuroblastoma RAS viral (v-ras) oncogene } \\
\text { homolog }\end{array}$ & XM_579607.1 & 910.25 & 601.06 & -1.5 & 0.0087 & 60 \\
\hline Brms1I_predicted & $\begin{array}{l}\text { Breast cancer metastasis-suppressor 1-like } \\
\text { (predicted) }\end{array}$ & XM_216712.3 & 187.93 & 125.37 & -1.5 & 0.0094 & 64 \\
\hline Hnrpde & $\begin{array}{l}\text { Heterogeneous nuclear ribonucleoprotein } \\
D(A U-\text { rich element RNA binding protein } 1 \text {, } \\
37 \mathrm{kDa})\end{array}$ & NM_024404.1 & 2909.16 & 1959.49 & -1.5 & 0.0010 & 8 \\
\hline Rpa2 & Replication protein A2 & NM_021582.1 & 1583.81 & 1154.73 & -1.4 & 0.0074 & 48 \\
\hline Ube2d3 & Ubiquitin-conjugating enzyme E2D 3 & NM_031237.1 & 123.48 & 99.45 & -1.2 & 0.0017 & 10 \\
\hline Lsm8_predicted ${ }^{\mathrm{e}}$ & $\begin{array}{l}\text { LSM8 homolog, U6 small nuclear RNA } \\
\text { associated (S. cerevisiae) (predicted) }\end{array}$ & XM_216102.3 & 3766.75 & 3121.49 & -1.2 & 0.0024 & 16 \\
\hline Smc1/1 & $\begin{array}{l}\text { Structural maintenance of chromosomes } 1 \\
\text { like } 1 \text { (S. cerevisiae) }\end{array}$ & NM_031683.1 & 4648.45 & 3923.73 & -1.2 & 0.0044 & 30 \\
\hline Rpa3_predicted & Replication protein A3 (predicted) & XM_216097.3 & 4013.83 & 3410.52 & -1.2 & 0.0022 & 14 \\
\hline \multicolumn{8}{|l|}{ Cell Signaling } \\
\hline Stip1 & $\begin{array}{l}\text { Stress-induced phosphoprotein } 1 \\
\text { (Stip1) }\end{array}$ & NM_138911.2 & 3478.09 & 2568.75 & -1.4 & 0.0028 & 18 \\
\hline \multicolumn{8}{|l|}{ Ubiquitination } \\
\hline Usp24_predicted & Ubiquitin specific protease 24 (predicted) & XM_233260.3 & 111.07 & 74.14 & -1.5 & 0.0037 & 25 \\
\hline Stub1_predicted & $\begin{array}{l}\text { STIP1 homology and U-Box containing } \\
\text { protein } 1 \text { (predicted) }\end{array}$ & XM_213270.3 & 4967.20 & 4164.69 & -1.2 & 0.0034 & 24 \\
\hline \multicolumn{8}{|l|}{ Ribosomal Proteins } \\
\hline Rps6 & Ribosomal protein S6 (Rps6) & NM_017160.1 & 29305.46 & 24538.18 & -1.2 & 0.0085 & 57 \\
\hline LOC300278 & Similar to 40 S ribosomal protein S9 & XM_213106.3 & 28115.69 & 26209.24 & -1.1 & 0.0086 & 59 \\
\hline LOC367102 & Similar to $40 S$ ribosomal protein S9 & XM_345948.2 & 25678.47 & 23353.32 & -1.1 & 0.0043 & 28 \\
\hline \multicolumn{8}{|l|}{ Others } \\
\hline Trpv2 & $\begin{array}{l}\text { Transient receptor potential cation channel, } \\
\text { subfamily V, member } 2\end{array}$ & NM_017207.1 & 177.90 & 92.25 & -1.9 & 0.0075 & 49 \\
\hline Gins3_predictede & GINS complex subunit 3 (Psf3 homolog) & XM_226235.2 & 171.57 & 89.64 & -1.9 & 0.0010 & 6 \\
\hline LOC499310 & Similar to cell division cycle associated 5 & XM_574612.1 & 450.69 & 270.81 & -1.7 & 0.0061 & 44 \\
\hline LOC298186 & $\begin{array}{l}\text { Similar to hypothetical protein FLJ33868 } \\
\text { (predicted) }\end{array}$ & XM_238399.3 & 271.10 & 177.29 & -1.5 & 0.0070 & 46 \\
\hline Terf1_predicted & $\begin{array}{l}\text { Telomeric repeat binding factor } 1 \\
\text { (predicted) }\end{array}$ & XM_238387.3 & 98.95 & 66.02 & -1.5 & 0.0048 & 34 \\
\hline LOC308004 & $\begin{array}{l}\text { Similar to hypothetical protein FLJ13188 } \\
\text { (predicted) }\end{array}$ & XM_217663.3 & 573.01 & 383.19 & -1.5 & 0.0083 & 56 \\
\hline LOC310177 & Similar to RIKEN cDNA 0610040D20 & XM_226872.2 & 85.32 & 58.03 & -1.5 & 0.0044 & 29 \\
\hline
\end{tabular}


Table 2 (Continued)

Genes with reduced expression in synovial fibroblasts from DA.F344 (Cia5d) compared with highly invasive DA, including those associated with cancer-phenotypes and estrogen signaling

\begin{tabular}{|c|c|c|c|c|c|c|c|}
\hline LOC297821 & Similar to F23N19.9 (predicted) & XM_232684.3 & 1680.52 & 1185.76 & -1.4 & 0.0052 & 36 \\
\hline LOC308443 & Similar to CDNA sequence BC028440 & XM_218345.2 & 426.63 & 301.59 & -1.4 & 0.0059 & 41 \\
\hline Anp32b & $\begin{array}{l}\text { Acidic nuclear phosphoprotein } 32 \text { family, } \\
\text { member B }\end{array}$ & NM_131911.2 & 454.58 & 323.06 & -1.4 & 0.0082 & 55 \\
\hline Ranbp6_predicted & RAN binding protein 6 (predicted) & XM_219796.2 & 309.74 & 222.79 & -1.4 & 0.0031 & 22 \\
\hline LOC297903 & $\begin{array}{l}\text { Similar to RIKEN cDNA } 6720467 \mathrm{C03} \\
\text { (predicted) }\end{array}$ & XM_216357.3 & 1493.92 & 1088.11 & -1.4 & 0.0075 & 50 \\
\hline Qdpr & Quinoid dihydropteridine reductase & NM_022390.1 & 983.32 & 728.72 & -1.3 & 0.0045 & 33 \\
\hline Rnf134_predicted & Ring finger protein 134 (predicted) & XM_219963.3 & 952.04 & 717.85 & -1.3 & 0.0059 & 42 \\
\hline LOC316731 & $\begin{array}{l}\text { Similar to hypothetical protein FLJ23017 } \\
\text { (predicted) }\end{array}$ & XM_237515.3 & 74.86 & 58.48 & -1.3 & 0.0094 & 65 \\
\hline LOC309197 & Similar to hypothetical protein & XM_219560.3 & 1413.35 & 1112.64 & -1.3 & 0.0050 & 35 \\
\hline LOC316732 & $\begin{array}{l}\text { Similar to RIKEN cDNA 4931400A14 } \\
\text { (predicted) }\end{array}$ & XM_244261.3 & 251.40 & 201.41 & -1.2 & 0.0062 & 45 \\
\hline Bin2_predicted & Bridging integrator 2 (predicted) & XM_578696.1 & 57.42 & 47.13 & -1.2 & 0.0076 & 51 \\
\hline
\end{tabular}

aEstrogen; ER, estrogen-induced, or estrogen-receptor signaling or degradation are marked in bold. bt test. 'Order (logistic regression) in the list of 66 genes differentially expressed between DA and DA.F344(Cia5d). ${ }^{d}$ Cancer and invasion associated genes are in italics. eDifferentially expressed in prostate, breast, colon or pharyngeal cancers. ${ }^{f K}$ nown to induce transcription or activation of gelatinases.

thermore, cluster analysis separated DA FLSs from DA.F344(Cia5d) FLSs, demonstrating that the two strains could be reliably differentiated by gene expression (Figure 2).

\section{Genes upregulated in the highly invasive DA FLSs and downregulated in DA.F344(Cia5d) include cancer- associated and invasion regulatory genes}

Cluster analysis identified three main clusters among the genes expressed in increased levels in DA (Figure 2). One of the three clusters contained eight genes, three of which have been implicated in cancer and cancer-related cellular phenotypes such as invasion, and included $\mathrm{Cxc} / 10$, Vil2 and Dnmbp (Figure 3$)$. The other genes in this cluster are involved in ion transport (Trpv2), mitosis (Smc1L1), or have incompletely characterized functions (Trim 16, Ranbp6 and Hnrpul2). In total, 12 out of the 36 genes (33.3\%) expressed in increased levels by DA FLSs and downregulated in DA.F344(Cia5d) are known to regulate cancer-associated processes, including cell cycle progression (Rpa2 and Rpa3), cell invasion (Cxc/10, Vil2, Nras, and Dnmbp), and metastasis (Vil2 and Brms1), respectively (Table 2 ). In fact, $\mathrm{C} x \mathrm{C} / 10$ was the second best discriminator between DA and DA.F344(Cia5d) cell lines, as per logistic regression (Table 2).

Of additional interest in relation to the MMP-2-dependent difference in FLS invasion that we have observed, three of these genes - namely $\mathrm{C} x \mathrm{C} / 10$, Vil2 and Nras - are known to regulate the synthesis or activation of gelatinases. Increased levels of Cxcl10, Vil2, Dnmbp, Trim16, and Trpv2 in DA were confirmed using quantitative real-time PCR, with most of these genes having a nearly fourfold or greater difference in expression $(P<0.05$; Figure 4a).
Genes downregulated in the highly invasive DA FLSs and upregulated in DA.F344(Cia5d) include tumor suppressor and cell cycle check-point genes

The list of genes with reduced expression in DA, as compared with increased expression in DA.F344(Cia5d) congenics, included seven genes that are involved in tumor suppressionlike activity and cell cycle check-points, such as Aph1a, Brwd3, Gadd45b, Gmfg, Lox, and Plekhg2 (Table 3). Gadd $45 b$ was chosen for quantitative real-time PCR confirmation ( $P<0.05$; Figure $4 \mathrm{~b}$ ). These observations, combined with the 11 cancer and invasion associated genes upregulated in DA, suggest an invasion-favoring profile similar to that described in cancer cells, characterized by reduced expression cell cycle check-point and tumor suppressor genes combined with increased expression of invasion genes.

\section{Additional genes with reduced expression in DA FLSs} Additionally, Ubxd2, Fzd4, Fkbp7, Olfm/2b, Gsdmdc1 and the transcriptional co-repressor Ncor1 were among the genes downregulated in DA and with increased expression in DA.F344(Cia5d). Gt/f3b (predicted), a gene trap fragment with unknown function, was among the most significantly differentially expressed genes $(P=0.000025 ; 2$.2-fold difference; Table 3$)$. The greater than twofold difference in expression of Olfm/2b and Gsdmdc1 was confirmed with quantitative real-time PCR (Figure 4b).

\section{Increased number of estrogen-inducible and ER signaling regulatory genes among the differentially expressed genes}

Nine genes or $13.6 \%$ of the 66 differentially expressed genes were either estrogen-inducible genes, such as $\mathrm{C} x \mathrm{c} / 10$, Vil2, 
Table 3

Genes with increased expression in synovial fibroblasts from DA.F344 (Cia5d) compared with DA

\begin{tabular}{|c|c|c|c|c|c|c|c|}
\hline Gene Symbold & Definition $^{a}$ & Accession number & DA mean & Cia5d mean & Fold change & $P$ value ${ }^{b}$ & Overall rank ${ }^{c}$ \\
\hline \multicolumn{8}{|c|}{ Cancer, Cell Cycle, DNA replication, recombination and repair } \\
\hline Gadd45b & $\begin{array}{l}\text { Growth arrest and DNA- } \\
\text { damage-inducible } 45 \text { beta }\end{array}$ & NM_001008321.1 & 214.12 & 412.97 & 1.9 & 0.00572 & 39 \\
\hline Gmfg & $\begin{array}{l}\text { Glia maturation factor, } \\
\text { gamma (Gmfg) }\end{array}$ & NM_181091.2 & 1359.39 & 2261.87 & 1.7 & 0.00817 & 54 \\
\hline Plekhg2_predicted & $\begin{array}{l}\text { Pleckstrin homology domain } \\
\text { containing, family G (with } \\
\text { RhoGef domain) member } 2 \\
\text { (predicted) }\end{array}$ & XM_214862.3 & 91.97 & 147.62 & 1.6 & 0.00784 & 52 \\
\hline Lox & Lysyl oxidase & XM_579391.1 & 15755.11 & 24559.79 & 1.6 & 0.00198 & 12 \\
\hline Brwd3_predicted & $\begin{array}{l}\text { Similar to bromo domain- } \\
\text { containing protein disrupted } \\
\text { in leukemia (LOC317213) }\end{array}$ & XM_228518.3 & 43.85 & 52.99 & 1.2 & 0.00596 & 43 \\
\hline Aph1a & $\begin{array}{l}\text { Similar to anterior pharynx } \\
\text { defective } 1 \text { homolog A (C. } \\
\text { elegans) }\end{array}$ & XM_345251.2 & 2820.66 & 3246.28 & 1.2 & 0.00046 & 4 \\
\hline Pex19_predictede & $\begin{array}{l}\text { Peroxisome biogenesis } \\
\text { factor } 19 \text { (predicted) }\end{array}$ & XM_225711.3 & 119.41 & 135.98 & 1.1 & 0.00561 & 38 \\
\hline \multicolumn{8}{|l|}{ Cell Signaling } \\
\hline Fkbp7_predicted & $\begin{array}{l}\text { FK506 binding protein } 7 \\
\text { (predicted) }\end{array}$ & XM_215758.3 & 784.02 & 1450.53 & 1.9 & 0.00578 & 40 \\
\hline Ncor1 & $\begin{array}{l}\text { Nuclear receptor co- } \\
\text { repressor } 1\end{array}$ & XM_577103.1 & 420.35 & 679.65 & 1.6 & 0.00454 & 32 \\
\hline Tap1 & $\begin{array}{l}\text { Transporter } 1 \text {, ATP-binding } \\
\text { cassette, sub-family B } \\
\text { (MDR/TAP) }\end{array}$ & NM_032055.1 & 190.32 & 288.49 & 1.5 & 0.00878 & 61 \\
\hline Prnp & Prion protein & XM_579340.1 & 17242.89 & 24050.29 & 1.4 & 0.00029 & 3 \\
\hline Fzd4 & $\begin{array}{l}\text { Frizzled homolog } 4 \\
\text { (Drosophila) }\end{array}$ & NM_022623.1 & 44.45 & 60.14 & 1.4 & 0.00406 & 26 \\
\hline \multicolumn{8}{|l|}{ Gene expression } \\
\hline $\mathrm{H} 1 \mathrm{fO}$ & $\mathrm{H} 1$ histone family, member 0 & NM_012578.2 & 150.12 & 229.40 & 1.5 & 0.00707 & 47 \\
\hline \multicolumn{8}{|l|}{ Cell-Cell Interaction } \\
\hline Fath & $\begin{array}{l}\text { Hypothetical gene } \\
\text { supported by NM_031819; } \\
\text { Fath fat tumor suppressor } \\
\text { homolog (Drosophila) }\end{array}$ & XM_579538.1 & 3803.04 & 5806.86 & 1.5 & 0.00206 & 13 \\
\hline \multicolumn{8}{|l|}{ Extracellular Matrix } \\
\hline Col5a1 & $\begin{array}{l}\text { Collagen, type V, alpha } 1 \\
\text { (Col5a1) }\end{array}$ & NM_134452.1 & 7240.26 & 9852.22 & 1.4 & 0.00807 & 53 \\
\hline \multicolumn{8}{|l|}{ Others } \\
\hline Gtlf3b_predicted & $\begin{array}{l}\text { Gene trap locus F3b } \\
\text { (predicted) }\end{array}$ & XM_343907.2 & 78.16 & 175.41 & 2.2 & 0.00003 & 1 \\
\hline Olfml2b_predicted & $\begin{array}{l}\text { Olfactomedin-like 2B } \\
\text { (predicted) }\end{array}$ & XM_222868.3 & 1336.30 & 2949.43 & 2.2 & 0.00241 & 17 \\
\hline
\end{tabular}


Table 3 (Continued)

\begin{tabular}{|c|c|c|c|c|c|c|c|}
\hline Gsdmdc1_predicted & $\begin{array}{l}\text { Gasdermin domain containing } 1 \\
\text { (predicted) }\end{array}$ & XM_235434.3 & 458.74 & 831.39 & 1.8 & 0.00295 & 20 \\
\hline Trim41_predicted & $\begin{array}{l}\text { Tripartite motif-containing } 41 \\
\text { (predicted) }\end{array}$ & XM_220357.3 & 422.66 & 732.37 & 1.7 & 0.00100 & 7 \\
\hline LOC498815 & $\begin{array}{l}\text { Hypothetical gene supported by } \\
\text { AY771707 }\end{array}$ & XM_579873.1 & 243.56 & 366.68 & 1.5 & 0.00281 & 19 \\
\hline LOC304860 & $\begin{array}{l}\text { Similar to } \mathrm{N} \text {-acetylneuraminate } \\
\text { pyruvate lyase }\end{array}$ & XM_222736.3 & 270.64 & 401.65 & 1.5 & 0.00176 & 11 \\
\hline Setdb2_predicted & $\begin{array}{l}\text { SET domain, bifurcated } 2 \\
\text { (predicted) }\end{array}$ & XM_224248.3 & 94.38 & 136.31 & 1.4 & 0.00945 & 66 \\
\hline LOC361448 & $\begin{array}{l}\text { Similar to cDNA sequence } \\
\text { BC013529 (predicted) }\end{array}$ & XM_341726.2 & 2852.12 & 4043.46 & 1.4 & 0.00071 & 5 \\
\hline LOC360899 & $\begin{array}{l}\text { Similar to SERTA domain } \\
\text { containing } 4\end{array}$ & XM_341174.2 & 1771.29 & 2489.20 & 1.4 & 0.00886 & 63 \\
\hline Ormdl2_predicted & $\begin{array}{l}\text { ORM1-like } 2 \text { (S. cerevisiae) } \\
\text { (predicted) }\end{array}$ & XM_213832.3 & 1996.56 & 2773.15 & 1.4 & 0.00549 & 37 \\
\hline LOC498067 & $\begin{array}{l}\text { Similar to RIKEN cDNA } \\
\text { 2310003P10 (LOC498067), } \\
\text { mRNA. }\end{array}$ & XM_573266.1 & 368.00 & 494.10 & 1.3 & 0.00860 & 58 \\
\hline Nit1 & Nitrilase 1 & NM_182668.1 & 3397.58 & 4472.84 & 1.3 & 0.00296 & 21 \\
\hline Fam18b_predicted & $\begin{array}{l}\text { Family with sequence similarity } \\
18, \text { member } B \text { (predicted) }\end{array}$ & XM_219680.3 & 2915.92 & 3746.20 & 1.3 & 0.00447 & 31 \\
\hline Ubxd2_predicted & $\begin{array}{l}\text { UBX domain containing } 2 \\
\text { (predicted) }\end{array}$ & XM_573443.1 & 2018.75 & 2569.23 & 1.3 & 0.00411 & 27 \\
\hline
\end{tabular}

aEstrogen; ER, estrogen-induced, or estrogen-receptor signaling or degradation are marked in bold. bt test. cOrder (logistic regression) in the list of 66 genes differentially expressed between DA and DA.F344(Cia5d). dCancer and invasion associated genes are in italics. elncreased expression in invading breast cancers.

Trim16, Gins3 (predicted), and Gadd45b, or genes involved in modulating the estrogen receptor (ER) signaling such as Stub1 and Stip1. Ncor1 negatively regulates ER-mediated transcription and its levels were also reduced in DA, further suggesting unopposed ER-mediated transcription. The differential expression of $\mathrm{Cxc} / 10$, Vil2, Trim16, Gins3, and Gadd45b was confirmed with quantitative real-time PCR (Figure $4 \mathrm{a}, \mathrm{b})$. The ERs Esr1 and Esr2 were not differentially expressed in the microarray analysis, and those results were confirmed with quantitative real-time PCR (Figure 4b). There was a trend toward increased expression Esr2 in DA.F344(Cia5d), but that difference did not reach statistical significance $(P=0.093$; Figure $4 \mathrm{~b})$. Taken together, this pattern of gene expression suggests that the invasive DA FLSs have an enhanced ER activity regulated at different levels that could include reduced degradation of the ER, reduced inhibition of the ER-mediated transcription, and increased levels of estrogen-inducible genes.

\section{Five of the differentially expressed genes are located within the Cia5d interval}

Five out of the 66 differentially expressed genes were located within the Cia5d interval (Table 4). The number of genes located within the Cia5d interval found to be differentially expressed between DA and DA.F344(Cia5d) FLSs was greater than would be expected by chance (3.3\% observed versus $0.8 \%$ expected by chance; $P=0.0044$ by $\chi^{2}$ with Yates correction; Table 5).
Trim 16, Trpv2, and Ncor1 are closely located on chromosome $10 q 23$, raising the possibility that a polymorphism in a regulatory region or intron in this region, or even in one of these genes, could account for the difference in expression detected between the two strains.

\section{Discussion}

RA histology is typically characterized by pronounced synovial hyperplasia, also called 'pannus'. The RA pannus produces proinflammatory cytokines and proteases, and invades cartilage and bone leading to joint destruction and deformities [4]. The FLS is a key player in RA pannus and joint pathology, and has increased invasive properties, compared with osteoarthritis, even after several passages in vitro $[12,27]$. Furthermore, the increased invasive properties of RA FLSs have been associated with increased radiographic joint destruction [13], underscoring the relevance of this in vitro phenotype to disease outcome.

We recently described the first evidence that the invasive properties of FLSs are genetically regulated [15]. We determined that a gene located within the arthritis severity regulatory Cia5d interval specifically controls the invasive properties of FLSs via the regulation of the production of soluble MT1MMP and activation of MMP-2 [15]. Levels of active MMP-2 are also increased in the synovial fluid of patients with RA, and correlate with disease severity and radiographic damage [28]. Therefore, understanding the regulation of cell invasion and 
Figure 2
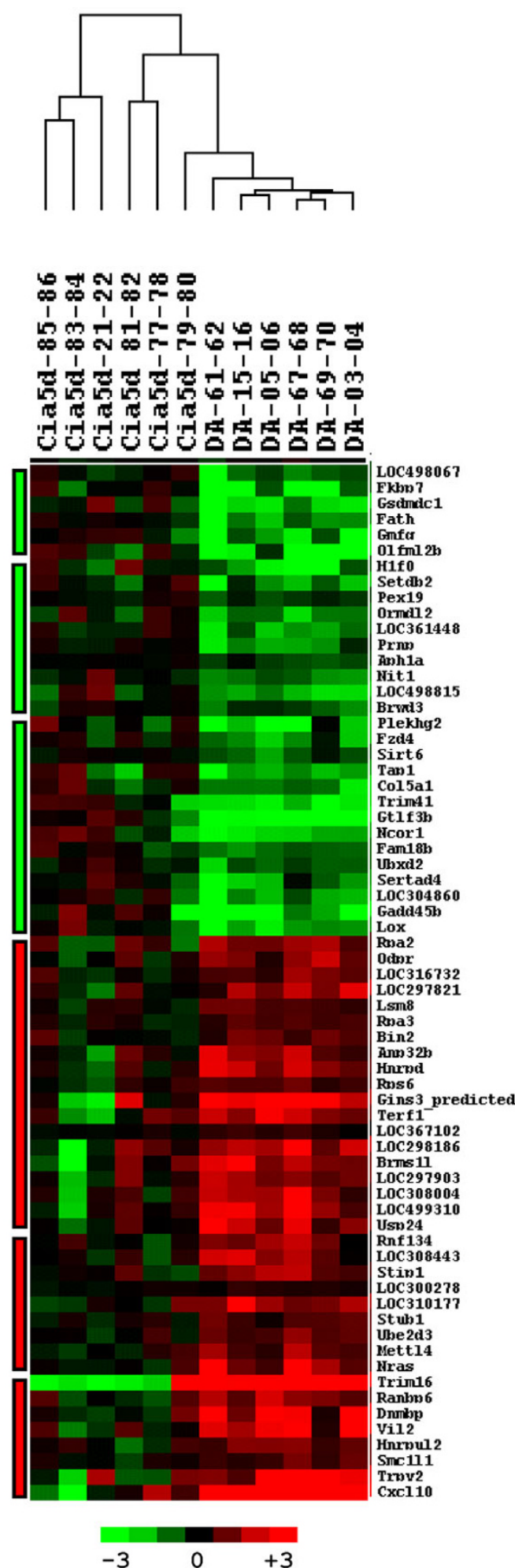

Cluster analysis and heat map of 66 differentially expressed genes. DA and DA.F344(Cia5d) samples are clustered on columns and genes on rows. Bars on the left side of the figure identify the three clusters of genes with reduced expression (green) and the three clusters of genes with increased expression (red) in DA compared with DA.F344(Cia5d).
Figure 3
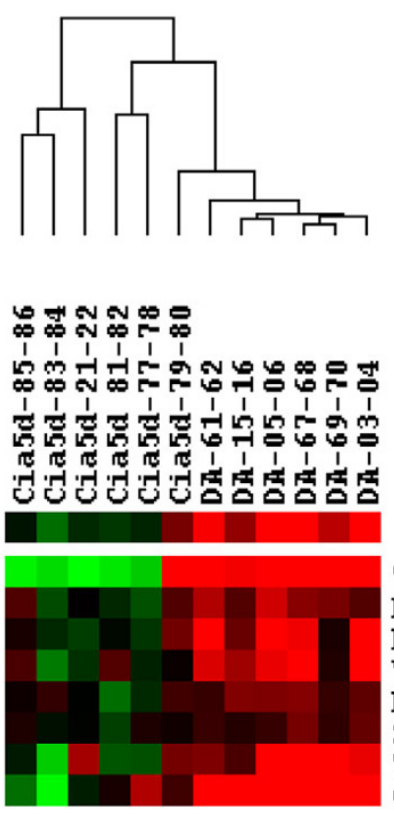

Trim16

Ranbv6

Dnmby

Vil2

Hnroul 2

Smc111

Truv2

$\operatorname{Cxc110}$

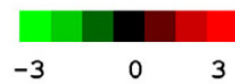

Cluster containing invasion and cancer-associated genes. Detailed view of the cluster that contains genes implicated in invasion and other cancer-associated phenotypes, including Cxc/10, Vil2 and Dnmbp.

MMP-2 activation is highly relevant to RA. In addition, several common cancers have increased levels of MMP-2, which correlates with worse prognosis [29-36], suggesting that identifying the Cia5d gene and the pathways controlled by it could potentially generate novel targets relevant to cancer treatment as well.

In the present study we used a novel strategy to identify differences in gene expression that correlate with the invasive properties of FLSs. First, two closely related strains were used. These strains have identical DA genomes, except that DA.F344(Cia5d) congenics have F344 arthritis-resistant alleles in a 37.2 megabase interval on chromosome 10. This strategy minimized noise related to allelic variations at other regions of the genome that are not related to the phenotype of interest. Second, instead of using synovial tissues, which have mixed cellularities that interfere with the interpretation of the results, we generate and used primary FLS cell lines. Third, FLSs from DA and DA.F344(Cia5d) differ in their invasive properties, thus providing a more precise phenotype. Finally, the cells used for RNA extractions were cultured on the same collagen matrix (Matrigel) used in the invasion experiments, hence recreating the same in vitro environment. This latter aspect is critical because extracellular matrix and cell influence processes that are central to cell invasion, such as the expression of adhesion molecules and MMP-2 activation [19], and 

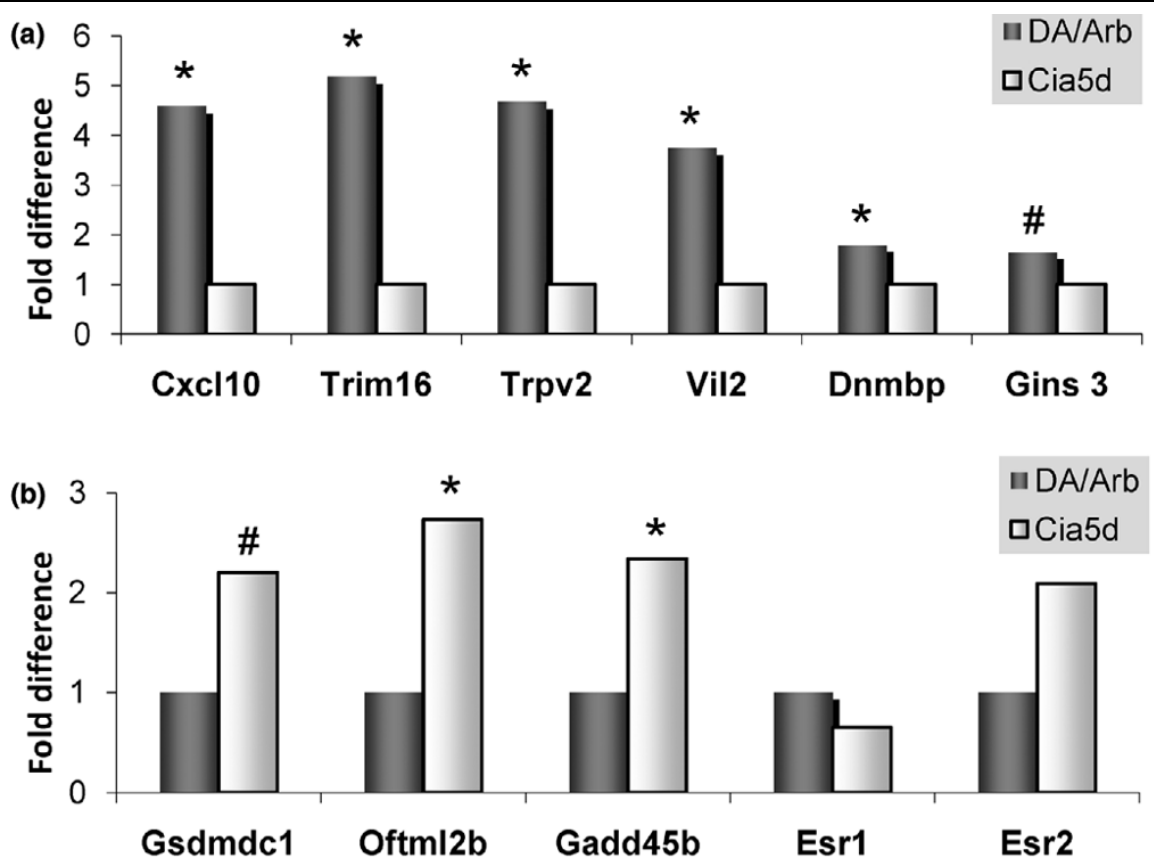

Quantitative real-time PCR. Presented are quantitative real-time PCR analysis of (a) genes upregulated in DA and downregulated in DA.F344(Cia5d), and (b) genes downregulated in DA and upregulated in DA.F344(Cia5d). These include invasion and cancer-associated genes and estrogen-inducible genes. Estrogen receptors Esr1 and Esr2 were also analyzed. ${ }^{\star} P<0.05,{ }^{\#} P<0.07$.

are required for proper activation of the invasive phenotype, including gene transcription. This strategy led to the identification of new genes involved in FLS invasion.

A genome-wide analysis of gene expression conducted with RA FLSs suggested two patterns that correlated with increased or reduced inflammation in the tissues of origin [37]. Those RA FLSs were not studied for invasion, and there was no control group without erosive changes for comparison. Furthermore, the RNA was obtained from cells cultured on plastic dishes and not on a collagen matrix such as Matrigel. Therefore, it was not surprising that using different methodologies to address a different question we detected a new FLS invasion signature that is different from the two RA FLS gene expression patterns previously reported.

A genome-wide microarray-based gene expression analysis was conducted to identify genes and pathways that are differentially expressed between highly invasive DA and minimally invasive DA.F344(Cia5d) FLSs. The analysis revealed that 66 genes out of the 7,665 genes expressed by FLSs were differentially expressed between DA and DA.F344(Cia5d) FLSs ( $P$ $<0.01)$. Nineteen of the 66 differentially expressed genes (28.7\%) had previously been implicated in tumor suppression activity or other cancer cell phenotypes, but had not been implicated in the invasive properties of the FLSs. These cancer-related phenotypes include malignant transformation (Hnrpd) [38], tumor growth (Ach1a and Gfmg) [39,40], oncogene-like activity (Plekgh2) [41], tumor apoptosis (Gadd45b)
[42], tumor suppressor activity (Brwd3) [43], cancer cell growth arrest (Ube2d3) [44], contact inhibition (Gmfg) [45], and cell invasion (Lox, Ach1a, Cxcl10, Vil2, and Nras) [46-50]. Genetic variations in DNA synthesis gene Rpa3 have been associated with susceptibility to carcinomas [51], whereas increased cancer expression of Rpa2 is associated with adverse outcome in colon cancer [52]. Some of these genes were found to be expressed in increased levels in certain cancers (Hnrpd and Lsm8) [53,54], including highly invasive types [55]. These observations suggest that FLSs derived from arthritis joints and cancer cells share common processes in the regulation of cell invasion, and that these processes are in part regulated by a gene located within the arthritis severity locus Cia5d.

Nras [56,57], Vil2 (encoding the ezrin protein) [49,50], and $\mathrm{CxC} / 10$ [58] - three genes that are upregulated in DA but downregulated in DA.F344(Cia5d) - have also been implicated in the regulation of gelatinases' expression and activation, including MMP-2 (Figure 5). These observations provide a direct link between the invasion and MMP-2 phenotypes that we have been studying and the gene expression signature regulated by the Cia5d locus. Furthermore, studies with RA synovial tissues [59,60] and RA FLSs [60] have also demonstrated increased expression of $\mathrm{C} x \mathrm{c} / 10$ both at mRNA and protein levels. $\mathrm{C} x \mathrm{C} / 10$ has also been shown to increase the production and activity of gelatinases in RA FLSs [61], underscoring the direct relevance of our in vitro discoveries to human disease. 
Table 4

\begin{tabular}{|c|c|c|c|c|c|c|c|c|c|}
\hline Symbol & Definition & $\begin{array}{c}\text { Accession } \\
\text { number }\end{array}$ & Position (Mb) & Cytogenetic & DA mean & Cia5d mean & Fold change & $t$ test & $\begin{array}{l}\text { Overall } \\
\text { rank }\end{array}$ \\
\hline \multicolumn{10}{|c|}{$\begin{array}{l}\text { Reduced } \\
\text { levels in Cia5d }\end{array}$} \\
\hline Trim16 & $\begin{array}{l}\text { Tripartite motif protein } 16 \\
\text { (predicted) } \\
\text { (Trim16_predicted) }\end{array}$ & XM_220552.3 & 48.95 & $10 q 23$ & 262.14 & 82.27 & -3.19 & 0.00326 & 23 \\
\hline Trpv2 & $\begin{array}{l}\text { Transient receptor potential } \\
\text { cation channel, subfamily V, } \\
\text { member } 2 \text { (Trpv2) }\end{array}$ & NM_017207.1 & 48.76 & $10 q 23$ & 177.90 & 92.25 & -1.93 & 0.00745 & 49 \\
\hline \multicolumn{10}{|c|}{$\begin{array}{l}\text { Increased } \\
\text { levels in Cia5d }\end{array}$} \\
\hline Ncor1 & $\begin{array}{l}\text { Nuclear receptor co- } \\
\text { repressor } 1 \text { (Ncor1) }\end{array}$ & XM_577103.1 & 48.62 & $10 q 23$ & 420.35 & 679.65 & 1.62 & 0.00454 & 32 \\
\hline Gtlf3b & $\begin{array}{l}\text { Gene trap locus F3b } \\
\text { (predicted) } \\
\text { (Gtlf3b_predicted) }\end{array}$ & XM_343907.2 & 47.05 & $10 q 22$ & 78.16 & 175.41 & 2.24 & 0.00003 & 1 \\
\hline Trim41 & $\begin{array}{l}\text { Tripartite motif-containing } \\
41 \text { (predicted) }\end{array}$ & XM_220357.3 & 34.08 & $10 q 21$ & 422.65 & 732.37 & 1.73 & 0.00099 & 7 \\
\hline
\end{tabular}

In addition to the proinvasive and MMP-2 activating properties associated with $\mathrm{Cxc} / 10$ in FLSs, this chemokine can also attract C-X-C chemokine receptor (CXCR)3-expressing inflammatory cells such as memory T cells [62] and mast cells [59] into the joint, further contributing to disease severity. Indeed, recent studies that either targeted $C_{x C / 10}$ [63] or its receptor CXCR3 [64] significantly ameliorated arthritis in rodents.

Cxc/10 [65], Vil2 [66], and Trim16 [67] - three of the most significantly upregulated genes in DA - are known to be induced by estrogens (Figure 5). A complete analysis of all of the 66 differentially expressed genes revealed that nine of them (13.6\%) were either regulated by estrogen ( $\mathrm{C} x \mathrm{C} / 10$, Vil2, Trim16, Gins3, Gadd45b, and Gmfg) [68] or are involved in ER signaling (Stip1), ER ubiquitination (Stub1), or ER-mediated transcription (Ncor 1). These observations suggested that abnormalities in the regulation of ER signaling and ER-mediated transcription could contribute to the invasive properties of DA FLSs. Indeed, estrogens have been shown to increase levels of active MMP-2 in various tissues and cell types [6971], including breast cancers [72], and estrogen antagonists reversed that effect $[71,73]$. Estrogens also increase the production of active MMP-2 and the in vitro invasive properties of
RA FLSs [74] (Figure 5). Although estrogens are typically thought of as having anti-inflammatory properties [75], our observations suggest an intrinsic dysregulation in ER signaling in DA FLSs. This dysregulation in ER is controlled by the Cia5d gene, and could contribute to increased FLS invasion and cartilage and bone erosive changes.

Five of the differentially expressed genes were located within the Cia5d interval, and this number was greater than expected by chance. Three of these were upregulated in DA.F344(Cia5d) FLS (Ncor1, Trim41, and Gt/f3b) and two were downregulated in DA.F344(Cia5d) (Trpv2 and Trim16), raising the possibility that a polymorphism/mutation in one of these genes could explain the arthritis and FLS invasive phenotypes attributed to Cia5d. Specifically, a polymorphism in a regulatory element or intron in one of these genes, or in another gene in the region, could influence transcription, thus explaining differences in levels of mRNA and disease. This has been the case in studies of two other autoimmune or inflammatory diseases in which microarray analysis led to the identification of the disease-causing polymorphism [76,77]. In the present study only Ncor1, a transcriptional repressor regulated by estrogens, appears to be an interesting candidate. Trpv2 is a cation channel ubiquitously expressed, and the

Table 5

A greater than expected number of genes located within the Cia5d interval were differentially expressed in FLSa

\begin{tabular}{lcc} 
& Differentially expressed & Not-differentially expressed \\
\hline Genes located within Cia5d & $5(3.3 \%)$ & 146 \\
Genes located outside Cia5d & $61(0.8 \%)$ & 7453 \\
\hline ap-value $=0.00442$ (Chi-square with Yates correction). &
\end{tabular}

ap-value $=0.00442$ (Chi-square with Yates correction). 


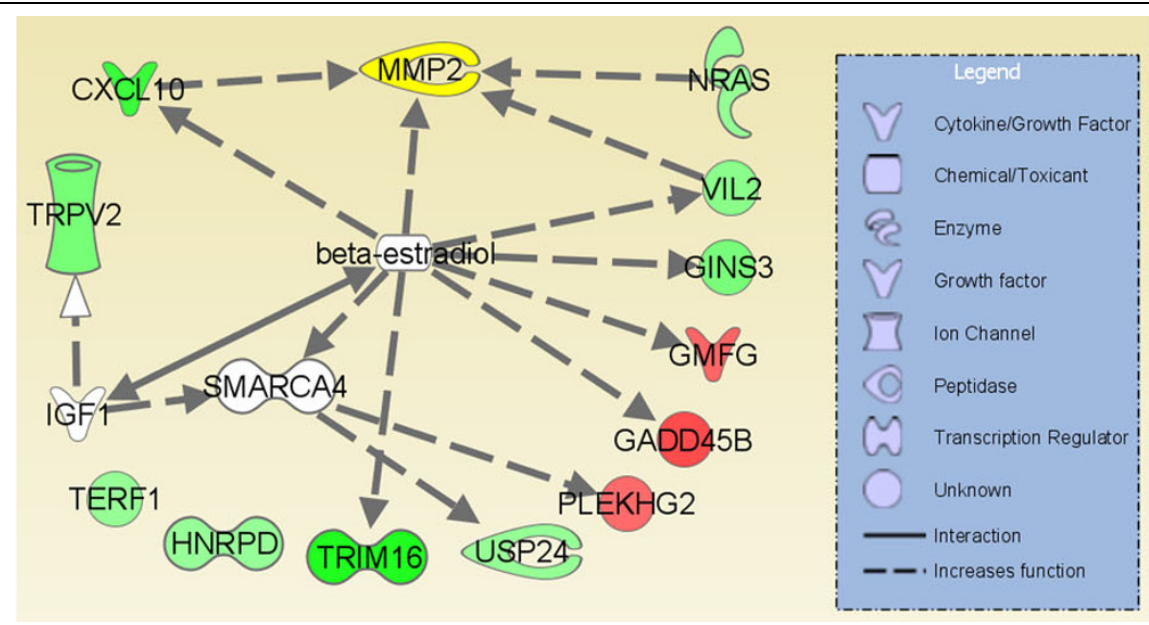

Known interactions between genes differentially expressed in FLSs from DA and DA.F344(Cia5d). Several estrogen ( $\beta$-estradiol)-regulated genes, including genes involved in increasing either the expression or activity of matrix metalloproteinase (MMP)-2, such as Cxc/10, Nras, and Vil2 were differentially expressed. Green indicates downregulated in DA.F344(Cia5d) and upregulated in DA. Red indicates upregulated in DA.F344(Cia5d) and downregulated in DA. White indicates that the gene is part of the pathway but was not differentially expressed in fibroblast-like synoviocytes (FLSs) from the two strains. Color intensity correlates with magnitude of the expression difference.

other three genes (Trim16, Trim41, and GtIf3b) have less clear functions. The Cia5d interval contains more than 100 genes, and not all were present in the Illumina microarray. It would be premature to exclude these genes at this point, and additional studies with recombinant subcongenic strains are under way.

\section{Conclusion}

We have identified a novel invasion-associated gene expression signature and evidence suggesting a dysregulation in ER signaling in arthritis FLSs, which are regulated by the arthritis severity locus Cia5d. It is anticipated that the specific identification of the Cia5d gene, and the continued characterization of processes regulated by this gene, will generate new targets for therapeutic intervention aimed at reducing cartilage and bone destruction, and new prognostic markers for RA. The parallels between our findings in FLSs and observations from cancer studies suggest that the Cia5d gene might be important for cancer biology as well.

\section{Competing interests}

The authors declare that they have no competing interests.

\section{Authors' contributions}

All authors made substantial contributions to this study. TL generated the FLS cell lines and worked on the gene expression analyses. MB conducted the cellular and molecular biology experiments. WL worked on the gene expression statistical analysis. PSG designed the study and conducted the microarray gene expression analysis and pathway discovery, and wrote the manuscript. All authors read the manuscript critically, suggested modifications, and approved the final version.

\section{Ackowledgments}

This study was funded by National Institutes of Health grants R01-AR46213, R01-AR052439 (NIAMS), and R01-AI54348 (NIAID) to Dr P Gulko. The authors want to thank Franak Batliwalla and Aarti Damle, members of the Feinstein Institute's microarray core facility, for their assistance.

\section{References}

1. Gregersen PK, Plenge RM, Gulko PS: Genetics of rheumatoid arthritis. In Rheumatoid Arthritis 2nd edition. Edited by: Firestein G, Panayi G, Wollheim FA. New York, NY: Oxford University Press; 2006:3-14.

2. Okada Y, Morodomi T, Enghild JJ, Suzuki K, Yasui A, Nakanishi I, Salvesen G, Nagase H: Matrix metalloproteinase 2 from human rheumatoid synovial fibroblasts. Purification and activation of the precursor and enzymic properties. Eur J Biochem 1990, 194:721-730.

3. Hanemaaijer R, Sorsa T, Konttinen $Y T$, Ding $Y$, Sutinen $M$, Visser $H$, van Hinsbergh VW, Helaakoski T, Kainulainen T, Rönkä H, Tschesche H, Salo T: Matrix metalloproteinase-8 is expressed in rheumatoid synovial fibroblasts and endothelial cells. Regulation by tumor necrosis factor-alpha and doxycycline. J Biol Chem 1997, 272:31504-31509.

4. Gulko PS, Winchester RJ: Rheumatoid arthritis. In Samter's Immunologic Diseases Volume II. 6th edition. Edited by: Austen KF, Frank MM, Atkinson JP, Cantor H. Baltimore, MD: Lippincott, Williams \& Wilkins; 2001:427-463.

5. Lee DM, Kiener HP, Agarwal SK, Noss EH, Watts GF, Chisaka O, Takeichi M, Brenner MB: Cadherin-11 in synovial lining formation and pathology in arthritis. Science 2007, 315:1006-1010.

6. Yellin MJ, Winikoff S, Fortune SM, Baum D, Crow MK, Lederman $\mathrm{S}$, Chess L: Ligation of CD40 on fibroblasts induces CD54 (ICAM-1) and CD106 (VCAM-1) up-regulation and IL-6 production and proliferation. J Leukoc Biol 1995, 58:209-216.

7. Fava RA, Olsen NJ, Postlethwaite AE, Broadley KN, Davidson JM, Nanney LB, Lucas C, Townes AS: Transforming growth factor beta 1 (TGF-beta 1) induced neutrophil recruitment to synovial tissues: implications for TGF-beta-driven synovial inflammation and hyperplasia. J Exp Med 1991, 173:1121-1132.

8. Shealy DJ, Wooley PH, Emmell E, Volk A, Rosenberg A, Treacy G, Wagner CL, Mayton L, Griswold DE, Song XY: Anti-TNF-alpha antibody allows healing of joint damage in polyarthritic transgenic mice. Arthritis Res 2002, 4:R7. 
9. Bischof RJ, Zafiropoulos D, Hamilton JA, Campbell IK: Exacerbation of acute inflammatory arthritis by the colony-stimulating factors CSF-1 and granulocyte macrophage (GM)-CSF: evidence of macrophage infiltration and local proliferation. Clin Exp Immuno/ 2000, 119:361-367.

10. Miagkov AV, Kovalenko DV, Brown CE, Didsbury JR, Cogswell JP, Stimpson SA, Baldwin AS, Makarov SS: NF-kappaB activation provides the potential link between inflammation and hyperplasia in the arthritic joint. Proc Natl Acad Sci USA 1998, 95:13859-13864.

11. Storgard CM, Stupack DG, Jonczyk A, Goodman SL, Fox RI, Cheresh DA: Decreased angiogenesis and arthritic disease in rabbits treated with an alphavbeta3 antagonist. J Clin Invest 1999, 103:47-54.

12. Muller-Ladner U, Kriegsmann J, Franklin BN, Matsumoto S, Geiler T, Gay RE, Gay S: Synovial fibroblasts of patients with rheumatoid arthritis attach to and invade normal human cartilage when engrafted into SCID mice. Am J Pathol 1996, 149:1607-1615.

13. Tolboom TC, Helm-Van Mil AH van der, Nelissen RG, Breedveld FC, Toes RE, Huizinga TW: Invasiveness of fibroblast-like synoviocytes is an individual patient characteristic associated with the rate of joint destruction in patients with rheumatoid arthritis. Arthritis Rheum 2005, 52:1999-2002.

14. Brenner M, Meng HC, Yarlett NC, Joe B, Griffiths MM, Remmers EF, Wilder RL, Gulko PS: The non-MHC quantitative trait locus Cia5 contains three major arthritis genes that differentially regulate disease severity, pannus formation, and joint damage in collagen- and pristane-induced arthritis. J Immunol 2005, 174:7894-7903.

15. Laragione T, Brenner M, Mello A, Symons M, Gulko PS: The arthritis severity locus Cia5d is a novel genetic regulator of the invasive properties of synovial fibroblasts. Arthritis Rheum 2008, 58:2296-2306

16. Vingsbo C, Sahlstrand P, Brun JG, Jonsson R, Saxne T, Holmdahl $R$ : Pristane-induced arthritis in rats: a new model for rheumatoid arthritis with a chronic disease course influenced by both major histocompatibility complex and non-major histocompatibility complex genes. Am J Pathol 1996, 149:1675-1683.

17. Gulko PS, Kawahito Y, Remmers EF, Reese VR, Wang J, Dracheva SV, Ge L, Longman RE, Shepard JS, Cannon GW, Sawitzke AD, Wilder RL, Griffiths MM: Identification of a new non-major histocompatibility complex genetic locus on chromosome 2 that controls disease severity in collagen-induced arthritis in rats. Arthrititis Rheum 1998, 41:2122-2131.

18. Remmers EF, Longman RE, Du Y, O'Hare A, Cannon GW, Griffiths MM, Wilder RL: A genome scan localizes five non-MHC loci controlling collagen-induced arthritis in rats. Nat Genet 1996, 14:82-85.

19. Preaux AM, Mallat A, Nhieu JT, D'Ortho MP, Hembry RM, Mavier P: Matrix metalloproteinase-2 activation in human hepatic fibrosis regulation by cell-matrix interactions. Hepatology 1999, 30:944-950.

20. Batliwalla FM, Baechler EC Xiao X, Li W, Balasubramanian S, Khalili H, Damle A, Ortmann WA, Perrone A, Kantor AB, Gulko PS, Kern M, Furie R, Behrens TW, Gregersen PK: Peripheral blood gene expression profiling in rheumatoid arthritis. Genes Immun 2005, 6:388-397.

21. Li W, Yang Y: Zipf's law in importance of genes for cancer classification using microarray data. J Theor Biol 2002, 219:539-551.

22. R statistical package [http://www.r-project.org/]

23. Eisen MB, Spellman PT, Brown PO, Botstein D: Cluster analysis and display of genome-wide expression patterns. Proc Natl Acad Sci USA 1998, 95:14863-14868.

24. Treeview [http://rana.lbl.gov]

25. Livak KJ, Schmittgen TD: Analysis of relative gene expression data using real-time quantitative PCR and the $2^{-\Delta \Delta C T}$ method. Methods 2001, 25:402-408.

26. Zimmermann T, Kunisch E, Pfeiffer R, Hirth A, Stahl HD, Sack U, Laube A, Liesaus E, Roth A, Palombo-Kinne E, Emmrich F, Kinne $\mathrm{RW}$ : Isolation and characterization of rheumatoid arthritis synovial fibroblasts from primary culture: primary culture cells markedly differ from fourth-passage cells. Arthritis Res 2001, 3:72-76.

27. Tolboom TC, Pieterman E, Laan WH van der, Toes RE, Huidekoper AL, Nelissen RG, Breedveld FC, Huizinga TW: Invasive proper- ties of fibroblast-like synoviocytes: correlation with growth characteristics and expression of MMP-1, MMP-3, and MMP10. Ann Rheum Dis 2002, 61:975-980.

28. Goldbach-Mansky R, Lee JM, Hoxworth JM, Smith D 2nd, Duray P, Schumacher RH Jr, Yarboro CH, Klippel J, Kleiner D, El-Gabalawy HS: Active synovial matrix metalloproteinase-2 is associated with radiographic erosions in patients with early synovitis. Arthritis Res 2000, 2:145-153.

29. Azzam HS, Arand G, Lippman ME, Thompson EW: Association of MMP-2 activation potential with metastatic progression in human breast cancer cell lines independent of MMP-2 production. J Natl Cancer Inst 1993, 85:1758-1764.

30. Abbas Abidi SM, Howard EW, Dmytryk JJ, Pento JT: Differential influence of antiestrogens on the in vitro release of gelatinases (type IV collagenases) by invasive and non-invasive breast cancer cells. Clin Exp Metastasis 1997, 15:432-439.

31. Garbisa S, Scagliotti G, Masiero L, Di Francesco C, Caenazzo C Onisto M, Micela M, Stetler-Stevenson WG, Liotta LA: Correlation of serum metalloproteinase levels with lung cancer metastasis and response to therapy. Cancer Res 1992, 52:4548-4549.

32. Gohji K, Fujimoto N, Fujii A, Komiyama T, Okawa J, Nakajima M: Prognostic significance of circulating matrix metalloproteinase-2 to tissue inhibitor of metalloproteinases-2 ratio in recurrence of urothelial cancer after complete resection. Cancer Res 1996, 56:3196-3198.

33. Vaisanen A, Kallioinen M, Taskinen PJ, Turpeenniemi-Hujanen $\mathrm{T}$ : Prognostic value of MMP-2 immunoreactive protein (72 kD type IV collagenase) in primary skin melanoma. J Pathol 1998, 186:51-58.

34. Nakada M, Okada Y, Yamashita J: The role of matrix metalloproteinases in glioma invasion. Front Biosci 2003, 8:e261-269.

35. Cockett MI, Murphy G, Birch ML, O'Connell JP, Crabbe T, Millican AT, Hart IR, Docherty AJ: Matrix metalloproteinases and metastatic cancer. Biochem Soc Symp 1998, 63:295-313.

36. Davies B, Waxman J, Wasan H, Abel P, Williams G, Krausz T, Neal $D$, Thomas D, Hanby A, Balkwill F: Levels of matrix metalloproteases in bladder cancer correlate with tumor grade and invasion. Cancer Res 1993, 53:5365-5369.

37. Kasperkovitz PV, Timmer TC, Smeets TJ, Verbeet NL, Tak PP, van Baarsen LG, Baltus B, Huizinga TW, Pieterman E, Fero M, Firestein GS, Pouw Kraan TC van der, Verweij CL: Fibroblast-like synoviocytes derived from patients with rheumatoid arthritis show the imprint of synovial tissue heterogeneity: evidence of a link between an increased myofibroblast-like phenotype and high-inflammation synovitis. Arthritis Rheum 2005, 52:430-441.

38. Gouble A, Grazide S, Meggetto F, Mercier P, Delsol G, Morello D: A new player in oncogenesis: AUF1/hnRNPD overexpression leads to tumorigenesis in transgenic mice. Cancer Res 2002, 62:1489-1495.

39. Paoni NF, Feldman MW, Gutierrez LS, Ploplis VA, Castellino FJ: Transcriptional profiling of the transition from normal intestinal epithelia to adenomas and carcinomas in the APCMin/+ mouse. Physiol Genomics 2003, 15:228-235.

40. Lim R, Liu YX, Zaheer A: Glia maturation factor beta regulates the growth of N18 neuroblastoma cells. Dev Biol 1990, 137:444-450

41. Himmel KL, Bi F, Shen H, Jenkins NA, Copeland NG, Zheng Y, Largaespada DA: Activation of clg, a novel dbl family guanine nucleotide exchange factor gene, by proviral insertion at evi24, a common integration site in $\mathrm{B}$ cell and myeloid leukemias. Biol Chem 2002, 277:13463-13472.

42. Qiu $W$, Zhou B, Chu PG, Luh F, Yen Y: The induction of growth arrest DNA damage-inducible gene 45 beta in human hepatoma cell lines by S-adenosylmethionine. Am J Pathol 2007, 171:287-296.

43. Muller P, Kuttenkeuler D, Gesellchen V, Zeidler MP, Boutros M: Identification of JAK/STAT signalling components by genomewide RNA interference. Nature 2005, 436:871-875.

44. Hattori $H$, Zhang $X$, Jia $Y$, Subramanian KK, Jo $H$, Loison $F$, Newburger PE, Luo HR: RNAi screen identifies UBE2D3 as a mediator of all-trans retinoic acid-induced cell growth arrest in human acute promyelocytic NB4 cells. Blood 2007, 110:640-650. 
45. Lim R, Nakagawa S, Arnason BG, Turriff DE: Glia maturation factor promotes contact inhibition in cancer cells. Proc Natl Acad Sci USA 1981, 78:4373-4377.

46. Kirschmann DA, Seftor EA, Fong SF, Nieva DR, Sullivan CM, Edwards EM, Sommer P, Csiszar K, Hendrix MJ: A molecular role for lysyl oxidase in breast cancer invasion. Cancer Res 2002, 62:4478-4483.

47. Poola I, DeWitty RL, Marshalleck JJ, Bhatnagar R, Abraham J, Leffall LD: Identification of MMP-1 as a putative breast cancer predictive marker by global gene expression analysis. Nat Med 2005, 11:481-483.

48. Zipin-Roitman A, Meshel T, Sagi-Assif O, Shalmon B, Avivi C, Pfeffer RM, Witz IP, Ben-Baruch A: CXCL10 promotes invasionrelated properties in human colorectal carcinoma cells. Cancer Res 2007, 67:3396-3405.

49. Alami J, Williams BR, Yeger $\mathrm{H}$ : Derivation and characterization of a Wilms' tumour cell line, WiT 49. Int J Cancer 2003, 107:365-374

50. Sizemore S, Cicek M, Sizemore N, Ng KP, Casey G: Podocalyxin increases the aggressive phenotype of breast and prostate cancer cells in vitro through its interaction with ezrin. Cancer Res 2007, 67:6183-6191.

51. Michiels S, Danoy P, Dessen P, Bera A, Boulet T, Bouchardy C, Lathrop M, Sarasin A, Benhamou S: Polymorphism discovery in 62 DNA repair genes and haplotype associations with risks for lung and head and neck cancers. Carcinogenesis 2007, 28:1731-1739.

52. Givalos N, Gakiopoulou H, Skliri M, Bousboukea K, Konstantinidou AE, Korkolopoulou P, Lelouda M, Kouraklis G, Patsouris E, Karatzas G: Replication protein $A$ is an independent prognostic indicator with potential therapeutic implications in colon cancer. Mod Pathol 2007, 20:159-166.

53. Waghray A, Schober M, Feroze F, Yao F, Virgin J, Chen YQ: Identification of differentially expressed genes by serial analysis of gene expression in human prostate cancer. Cancer Res 2001, 61:4283-4286.

54. Chow LS, Lam CW, Chan SY, Tsao SW, To KF, Tong SF, Hung WK, Dammann R, Huang DP, Lo KW: Identification of RASSF1A modulated genes in nasopharyngeal carcinoma. Oncogene 2006, 25:310-316.

55. lacobuzio-Donahue CA, Argani P, Hempen PM, Jones J, Kern SE: The desmoplastic response to infiltrating breast carcinoma: gene expression at the site of primary invasion and implications for comparisons between tumor types. Cancer Res 2002, 62:5351-5357.

56. Yoshida T, Hisamoto T, Akiba J, Koga H, Nakamura K, Tokunaga $Y$, Hanada S, Kumemura H, Maeyama M, Harada M, Ogata H, Yano H, Kojiro M, Ueno T, Yoshimura A, Sata M: Spreds, inhibitors of the Ras/ERK signal transduction, are dysregulated in human hepatocellular carcinoma and linked to the malignant phenotype of tumors. Oncogene 2006, 25:6056-6066.

57. Thant AA, Sein TT, Liu E, Machida K, Kikkawa F, Koike T, Seiki M, Matsuda S, Hamaguchi M: Ras pathway is required for the activation of MMP-2 secretion and for the invasion of src-transformed 3Y1. Oncogene 1999, 18:6555-6563.

58. Pellegrino A, Antonaci F, Russo F, Merchionne F, Ribatti D, Vacca A, Dammacco F: CXCR3-binding chemokines in multiple myeloma. Cancer Lett 2004, 207:221-227.

59. Ruschpler P, Lorenz P, Eichler W, Koczan D, Hanel C, Scholz R, Melzer C, Thiesen HJ, Stiehl P: High CXCR3 expression in synovial mast cells associated with CXCL9 and CXCL10 expression in inflammatory synovial tissues of patients with rheumatoid arthritis. Arthritis Res Ther 2003, 5:R241-R252.

60. Ueno A, Yamamura M, Iwahashi M, Okamoto A, Aita T, Ogawa N, Makino $\mathrm{H}$ : The production of CXCR3-agonistic chemokines by synovial fibroblasts from patients with rheumatoid arthritis. Rheumatol Int 2005, 25:361-367.

61. Garcia-Vicuna R, Gomez-Gaviro MV, Dominguez-Luis MJ, Pec MK, Gonzalez-Alvaro I, Alvaro-Gracia JM, Diaz-Gonzalez F: CC and CXC chemokine receptors mediate migration, proliferation, and matrix metalloproteinase production by fibroblast-like synoviocytes from rheumatoid arthritis patients. Arthritis Rheum 2004, 50:3866-3877.

62. Holse M, Assing K, Poulsen LK: CCR3, CCR5, CCR8 and CXCR3 expression in memory $\mathrm{T}$ helper cells from allergic rhinitis patients, asymptomatically sensitized and healthy individuals. Clin Mol Allergy 2006, 4:6.
63. Salomon I, Netzer N, Wildbaum G, Schif-Zuck S, Maor G, Karin N: Targeting the function of IFN-gamma-inducible protein 10 suppresses ongoing adjuvant arthritis. J Immunol 2002, 169:2685-2693.

64. Mohan K, Issekutz TB: Blockade of chemokine receptor CXCR3 inhibits T cell recruitment to inflamed joints and decreases the severity of adjuvant arthritis. J Immuno/ 2007, 179:8463-8469.

65. Sentman CL, Meadows SK, Wira CR, Eriksson M: Recruitment of uterine NK cells: induction of CXC chemokine ligands 10 and 11 in human endometrium by estradiol and progesterone. Immunol 2004, 173:6760-6766.

66. Smith PM, Heinrich CA, Pappas S, Peluso JJ, Cowan A, White BA: Reciprocal regulation by estradiol 17-beta of ezrin and cadherin-catenin complexes in pituitary $\mathrm{GH} 3$ cells. Endocrine 2002, 17:219-228.

67. Liu HL, Golder-Novoselsky E, Seto MH, Webster L, McClary J, Zajchowski DA: The novel estrogen-responsive B-box protein (EBBP) gene is tamoxifen-regulated in cells expressing an estrogen receptor DNA-binding domain mutant. Mol Endocrinol 1998, 12:1733-1748.

68. Moggs JG, Murphy TC, Lim FL, Moore DJ, Stuckey R, Antrobus K Kimber I, Orphanides G: Anti-proliferative effect of estrogen in breast cancer cells that re-express ERalpha is mediated by aberrant regulation of cell cycle genes. $J \mathrm{Mol}$ Endocrinol 2005 , 34:535-551.

69. Helvering LM, Adrian MD, Geiser AG, Estrem ST, Wei T, Huang S, Chen P, Dow ER, Calley JN, Dodge JA, Grese TA, Jones SA, Halladay DL, Miles RR, Onyia JE, Ma YL, Sato M, Bryant HU: Differential effects of estrogen and raloxifene on messenger RNA and matrix metalloproteinase 2 activity in the rat uterus. Biol Reprod 2005, 72:830-841.

70. Paquette B, Bisson $M$, Therriault $H$, Lemay $R$, Pare $M$, Banville $P$ Cantin AM: Activation of matrix metalloproteinase-2 and -9 by 2- and 4-hydroxyestradiol. J Steroid Biochem Mol Biol 2003, 87:65-73.

71. Wingrove CS, Garr E, Godsland IF, Stevenson JC: 17betaoestradiol enhances release of matrix metalloproteinase-2 from human vascular smooth muscle cells. Biochim Biophys Acta 1998, 1406:169-174.

72. Etique N, Grillier-Vuissoz I, Flament S: Ethanol stimulates the secretion of matrix metalloproteinases 2 and 9 in MCF-7 human breast cancer cells. Oncol Rep 2006, 15:603-608.

73. Mitropoulou TN, Tzanakakis GN, Kletsas D, Kalofonos HP, Karamanos NK: Letrozole as a potent inhibitor of cell proliferation and expression of metalloproteinases (MMP-2 and MMP-9) by human epithelial breast cancer cells. Int J Cancer 2003, 104:155-160.

74. Khalkhali-Ellis Z, Seftor EA, Nieva DR, Handa RJ, Price RH Jr, Kirschmann DA, Baragi VM, Sharma RV, Bhalla RC, Moore TL, Hendrix $\mathrm{MJ}$ : Estrogen and progesterone regulation of human fibroblast-like synoviocyte function in vitro: implications in rheumatoid arthritis. J Rheumato/ 2000, 27:1622-1631.

75. Straub $\mathrm{RH}$ : The complex role of estrogens in inflammation. Endocr Rev 2007, 28:521-574.

76. Rozzo SJ, Allard JD, Choubey D, Vyse TJ, Izui S, Peltz G, Kotzin BL: Evidence for an interferon-inducible gene, Ifi202, in the susceptibility to systemic lupus. Immunity 2001, 15:435-443.

77. Karp CL, Grupe A, Schadt E, Ewart SL, Keane-Moore M, Cuomo PJ, Köhl J, Wahl L, Kuperman D, Germer S, Aud D, Peltz G, WillsKarp M: Identification of complement factor 5 as a susceptibility locus for experimental allergic asthma. Nat Immunol 2000, $1: 221-226$. 